\title{
Mistletoes of Khimti forest, Ramechhap
}

\author{
Mohan P. Devkuta ${ }^{1}$
}

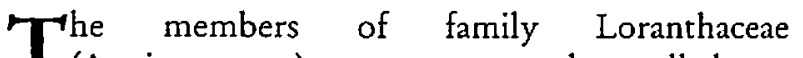
1 (Angiospermae) are commonly called as Mistletoe in English and Ainjeru or Lisso in Nepali. The family comprises mostly lianas, undershrubs or shrubs but rarely trees. The members of this family are exclusively tropical to sub-tropical whereas only a handful species have successfully established themselves elsewhere (Johri and Bhatnagar 1972). Mistletoe generally parasitise the stem, and rarely roots of wide range of plants varying from aesthetic, ornamental, medicinal and economic values. These plants have unusual habit of hemiparasitic shrubs that grows on host trees with the help of modified roots called haustorium. Mistletoe can be easily identified growing luxuriantly on host trees by forming evergreen shrub like appearance of various sizes. Leaves of mistletoe are generally thick and leathery and the small flowers are showy, brightly colored and nectar producing. Pollination is usually through birds.
\end{abstract}

Mistletoe are responsible to reduce the vigor and growth rate of host plants, poor fruiting and seed production, formation of burrs on trunks or branches, reduction in foliage, drying of tops and even premature death. Research on various aspects of this perticular member of plant life has yet to draw attention in Nepal. The present enumeration which was carried out at the relatelively protected forests at Khimti will, therefore, add to our understanding on this subject area.

\section{Study area}

The study area covers the places between Jiri (1970 $\mathrm{m})$ to the Khimti Besi $(600 \mathrm{~m})$. The area $\left(27^{\circ} 28^{\prime}\right.$ and $27^{\circ} 45^{\prime}$ North and $86^{\circ} 07^{\prime}$ and $86^{\circ} 26^{\prime}$ East) is located near the boundaries of Dolkha and Ramechap districts of Janakpur Zone. It has an altitudinal variation of $600 \mathrm{~m}$ to $4000 \mathrm{~m}$ and has, therefore, a well defined ecological characters.

\section{Results}

Seven species of mistletoe belonging to family Loranthaceae were found parasitising on twelve host trees of ten families. Scurrula pulverulenta (Wall.) D. Don is widely distributed in the basin on seven host trees whereas Viscum album Linn. was observed on only one tree. Schimma wallichii (DC.) Korth was found to be the common host of three mistletoe species.

The mistletoe in the Khimti basin are localised in the scattered patches of natural forests, most of which are protected by the local communities. The rare sight of miseltoe in degraded forests of basin, and a sizable population of luxuriantly growing mistletoe observed in such areas is similar to the previous results of Devkota Acharya (1995) who reported that the places of little human disturbance have good composition of mistletoes. A wide range of hosts-mistletoes observed in the present study indicates that the area is suitable for the growth of miseltoes (Table)

Forests located on mountain slopes facing towards the sun (South/East and South/West) had higher number of mistletoes. The trees on forest margins were found severely infected with mistletoes than those at the center.

Of the various mistletoes, Viscum orientale Willd. was found near Kholme and Palati villages, to be host specific preferring highly Englebardtia spicata as its host

Presence of trees such as Rbododendron arboreum that produces nectarius flower was found to be the other factor effecting the distribution of milteletoes. Also this is related with the Loranthoideae birds, particularly the sunbirds (Necteriniidae) and the mistletoe birds or flower peckers (Dicaeidae) are the principal pollinating agents of mistletoe (Ali 1932). These birds depend upon the nectar as a main source of food and help pollinate mistletoe. Firebreasted flower pecker (Dicaeum ignipectus) of Dicaeidae group was observed many times feeding upon the ripen berries of mistletoe in the forest. Birds of Dicaeidae group live, at a certain time of the year, upon the ripe mistletoe fruits (Reid 1991). Undigested seeds of mistletoe gets transported by

\footnotetext{
'Assisstant Lecturer, Botany Department, Amrit Science Campus, Thamel, Kathmandu
} 
Table : Mistletoe growing on various hosts at Khimti forest

\begin{tabular}{|c|c|c|}
\hline $\begin{array}{l}\text { S. } \\
\text { No. }\end{array}$ & Mistleto & Host \\
\hline 1 & Helixenthera ligustrina (Wall.) Danser & $\begin{array}{l}\text { Schima wallichii (DC) Korth } \\
\text { Woodfordia fruticosa (L) Kurtz }\end{array}$ \\
\hline 2 & Macrosolen cochenchinensis (Lour.) Van Tiegh & $\begin{array}{l}\text { Lyonia ovalifolia (Wall) Drude } \\
\text { Schima wallichii (DC) Korth }\end{array}$ \\
\hline 3 & Scurrula parasitica Linn. & $\begin{array}{l}\text { Rhododendron arboreum J. E. Smith } \\
\text { Lyonia ovalifolia (Wall) Drude } \\
\text { Pyrus pashia Buch. - Ham. ex. D. Don } \\
\text { Fraxinus floribunda Wall }\end{array}$ \\
\hline 4 & Scurrula pulverulenta (Wall.) G. Don & $\begin{array}{l}\text { Alnus nepalensis D. Don } \\
\text { Lyonia ovalifolia (Wall) Drude } \\
\text { Rhododendron arboreum J. E. Smith } \\
\text { Berberis aristata DC } \\
\text { Shorea robusta Gaertn. f. } \\
\text { Schima wallichii DC. Korth } \\
\text { Pyrus communis }\end{array}$ \\
\hline 5 & Viscum album Linn. & Alnus nepalensis D. Don \\
\hline 6 & Viscum orientale Willd. & $\begin{array}{l}\text { Englehardtia spicata Leschen. ex Blume } \\
\text { Shorea robusta Gaertn. f. } \\
\text { Xylosma controversum Clos. }\end{array}$ \\
\hline
\end{tabular}

these birds to the neighboring trees and sometime even to the neighboring forest thereby helping their dispersal.

\section{Economic importance of mistletoe}

Despite economic value, very few species of mistletoes have been exploited in Nepal. In some remote parts of Nepal the decoction from the ripen berries is used by the villagers to trap birds and mice. Occasionally the ripen berries which are sweet, are also eaten raw by the villagers.

Plant product of Viscum species are often mixed with egg and eaten to cure fractures in the remote villages of Nepal. Berries of $V$. album are laxative, tonic, aphrodisiac, diuretic and cardiotonic. They are also used in the treatment of spleen, ear diseases and tumors. The products of Maccrosolen cocbenchinensis are used during headache and child birth and for curing oedematous tumors in India (Johri and Bhatnagar 1972).
For such values, the ethnobotanical studies on mistletoes, along with their diversity and ecology, should be conducted in Nepal.

\section{References}

Ali, S. A. 1931. The role of the sunbirds and flower peckers in propagationand distribution of tree parasites, Loranthus longiflorus in Konkan. Jour. Bombay Nat. Hist. Soc. 35: 144-149.

Devkota, M.P. and Acharya, N. 1995. Status of Angiospermic Tree Parasitic of Kathmandu Valley. A report submitted to World Wildlife Fund, Nepal Program, Kathmandu.

Johri, B.M. and Bhatnagar, S.P. 1972. Botanical Monograph No. 8. Loranthaceae.

Reid, N. 1991 Coevolution of mistletoe and frugivorous birds. Australian Journal of Ecology. 16 (475-469) 